\title{
Case Report: \\ VENTRICULOPERITONEAL SHUNT CATHETER MIGRATION AND TRANSANAL EXTRUSION IN PERSISTENT VEGETATIVE STATE ADULT PATIENT
}

\author{
Asra Al Fauzi, Muhammad Arifin Parenrengi, Joni Wahyuhadi, Eko Agus Subagio, Agus Turchan \\ Department of Neurosurgery, Faculty of Medicine, Universitas Airlangga, Surabaya Neuroscience Institute, \\ Dr. Soetomo Academic Medical Center Hospital, Surabaya, Indonesia
}

\begin{abstract}
The complications of ventriculoperitoneal (VP) shunts are many and are reported in literature extensively. The complication of transanal extrusion after bowel perforation is known although rare. This complication is very well described amongst the children. The authors describe the case of bowel perforation and transanal extrusion of a VP shunt occurring in a 51-year-old adult patient. The patient has a history of craniotomy for acute subdural hematoma after severe head injury one year ago continued with VP shunt for post-traumatic hydrocephalus. Home care with bedridden conditions is done at home until finally, the family gets the catheter extrude from the transanal. Bowel perforation and transanal extrusion of VP shunt catheter is a rare but serious problem. The exact pathogenesis of shunt-related organ perforation and extrusion through the anus is unclear, and various mechanisms have been suggested, Among many factors, age is the prominent factor for bowel perforation.1 Because of weak bowel musculature and stronger peristaltic activity, children are more susceptible to bowel perforation than adult patients. In adult shunted patient, one of the risk factors is related to PVS with chronic immobilization, as described in this case. Risk factors of bowel perforation in adult are quite distinct from children. Persistent vegetative state (PVS) with chronic immobilization is one of the risk factors to be aware of.
\end{abstract}

Keywords: Ventriculoperitoneal shunt; transanal extrusion; persistent vegetative state; adult patient

\section{ABSTRAK}

Komplikasi ventriculoperitoneal (VP) shunt sudah banyak terjadi dan dilaporkan dalam berbagai literatur secara luas. Komplikasi ekstrusi transanal setelah perforasi usus juga telah diketahui meskipun angka kejadiannya masih jarang. Komplikasi ini telah jamak dijelaskan dan diketahui sering terjadi pada anak-anak. Para penulis melaporkan sebuah kasus perforasi usus dan ekstrusi transanal dari VP shunt yang terjadi pada seorang pasien dewasa berusia 51 tahun. Pasien tersebut memiliki riwayat kraniotomi untuk hematoma subdural akut setelah cedera kepala parah satu tahun yang lalu, dilanjutkan dengan VP shunt untuk hidrosefalus pasca trauma. Perawatan dengan kondisi bed ridden dilakukan di rumah, sampai akhirnya keluarga mendapati adanya kateter yang keluar dari lubang anus. Perforasi usus dan ekstrusi transanal dari $V P$ shunt catheter adalah masalah yang cukup jarang namun perlu pehatian serius. Patogenesis pasti dari perforasi organ yang berhubungan dengan shunt dan ekstrusi melalui anus tidaklah jelas, dan berbagai mekanisme telah disarankan, di antara banyak faktor, usia adalah faktor utama untuk perforasi usus.1 Karena otot-otot usus yang lemah dan aktivitas peristaltik yang lebih kuat, anak-anak lebih rentan terhadap perforasi usus daripada pasien dewasa. Pada pasien dewasa yang menggunakan shunt, salah satu faktor risikonya adalah berhubungan dengan Persistent Vegetative State (PVS) dan imobilisasi kronis, seperti yang dijelaskan dalam kasus ini. Faktor risiko perforasi usus pada orang dewasa cukup berbeda dari anak-anak. PVS dengan imobilisasi kronis adalah salah satu faktor risiko yang harus diperhatikan.

Kata kunci: Ventriculoperitoneal shunt; transanal extrusion; persistent vegetative state; pasien dewasa

Correspondence: Asra Al Fauzi, Department of Neurosurgery, Faculty of Medicine, Universitas Airlangga, Dr. Soetomo Academic Medical Center Hospital, Jalan Prof. Dr. Moestopo 6-8, Surabaya 60286, Indonesia. Mobile phone : +6281-333934999, Fax : +6231-5025188, E-mail : asra-a-f-11@pasca.unair.ac.id

pISSN:2355-8393 • eISSN: 2599-056x • doi: http://dx.doi.org/10.20473/fmi.v55i4.17336

- Fol Med Indones. 2019;55:322-325 • Received 28 Mar 2019 • Accepted 24 Aug 2017

- Open access under CC-BY-NC-SA license $\bullet$ Available at https://e-journal.unair.ac.id/FMI/ 


\section{INTRODUCTION}

Ventriculoperitoneal (VP) shunting is the most widely used procedure in the treatment of hydrocephalus (Sathyanarayana et al 2000, Vinchon et al 2006, Matsuoka, Takegami \& Maruyama, 2008, Filho et al 2013). The procedure is associated with various complications (Sridhar \& Karmarkar, 2009, Glatstein et al 2011, Yilmaz et al 2011). The common complications are infection, malfunction due to blockage, disconnection, migration and shunt failure (Sathyanarayana et al 2000, Vinchon et al 2006, Matsuoka, Takegami and Maruyama, 2008, Glatstein et al 2011, Filho et al 2013). The reported incidence of abdominal complications is 5\% - 47\% (Yazar et al 2012, Filho et al 2013). Bowel perforation and spontaneous extrusion of distal catheter through the anal orifice especially in adult case are very rare and only few cases reported in the literature (Sathyanarayana et al 2000, Birbilis et al 2009, Filho et al 2013). The author reporting one such rare case of transanal extrusion of peritoneal catheter in adult patient.

\section{CASE REPORT}

A fifty-one-year-old PVS and a bedridden male patient were brought to our hospital after his family noticed a VP shunt catheter extruding from his anus. One year earlier, the patient had undergone VP shunt placement for hydrocephalus following craniotomy for traumatic subdural hemorrhage after severe head injury. Postoperatively the patient was in PVS and continued for home nursing. $\mathrm{He}$ is in bedridden state and in continuous nasogastric tubing for his routine diet. One week before admitted to the hospital, he suffered from repeated diarrhea and then in the following day his wife noticed a tube came up from the anus. On examination, there was a tip of the peritoneal catheter extruded five centimeters from the anus and no cerebrospinal fluid drip was detected. There was no sign of meningeal sign or increased intracranial pressure, no distention or abdominal tenderness. The patient was in PVS with spontaneous eye opening and no verbal contact. The result of laboratory examinations showed no infection process with hypoalbuminemia and anemia. Abdominal $\mathrm{x}$-ray film demonstrated the peritoneal catheter entering the descendent colon and exiting through the anus (Figs. 1 and 2).

The patient underwent emergency shunt removal. Analysis of the cerebrospinal fluid did not reveal any signs of infection. We removed the whole catheter and observed the patient for two days. External drainage was not performed. During the observation, there was no sign and symptoms of increasing intracranial pressure. There were no signs of meningitis or peritonitis. After five days of treatment, the patient was discharged home in satisfactory result with the same permanent condition.

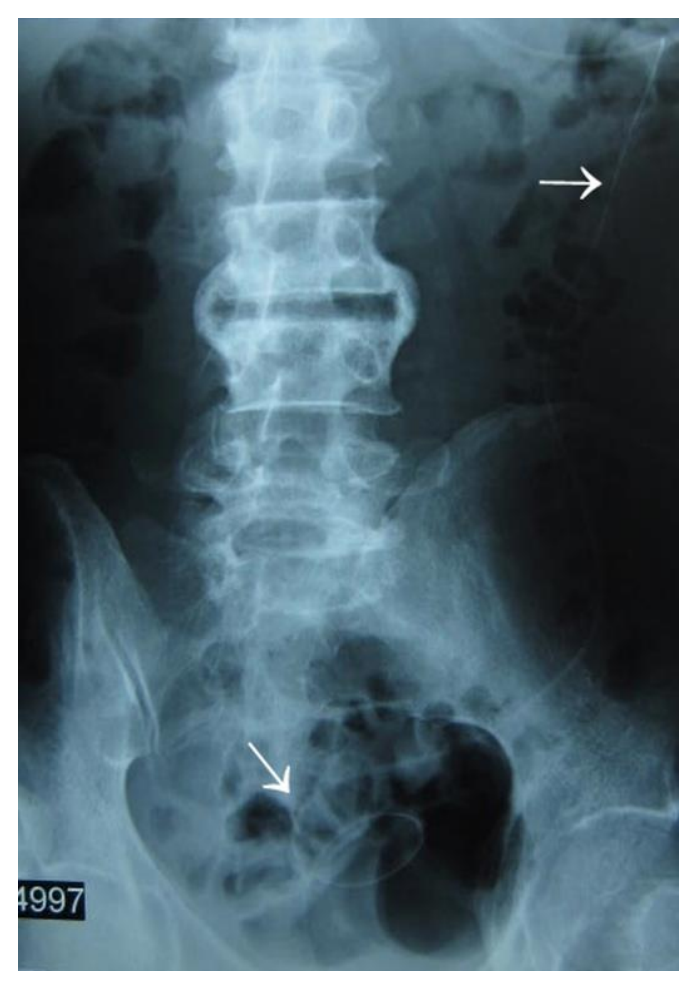

Fig. 1. Abdominal x-ray film of peritoneal catheter entering the descendent colon.

\section{DISCUSSION}

The ventriculoperitoneal shunt has been the mainstay of treatment of hydrocephalus since the development of valve systems in the 1950s (Sathyanarayana et al 2000, Vinchon et al 2006, Matsuoka, Takegami and Maruyama, 2008, Filho et al 2013). Many complications that may follow the insertion of a VP shunt have been described (Sathyanarayana et al 2000, Vinchon et al 2006, Matsuoka et al 2008, Glatstein et al 2011, Filho et al 2013). The incidence of bowel perforation by peritoneal catheter has been estimated to range between 0,1 to $0,7 \%$ of shunted patients (Vinchon et al 2006, Murthy \& Reddy 2009). Spontaneous bowel perforation is a rare complication of VP shunting and mostly affected pediatric patients (Sathyanarayana et al 2000, Birbilis et al 2009, Filho et al 2013). Anal extrusion has been reported in a minority of patients with bowel perforation (Vinchon et al 2006, Filho et al 2013). 


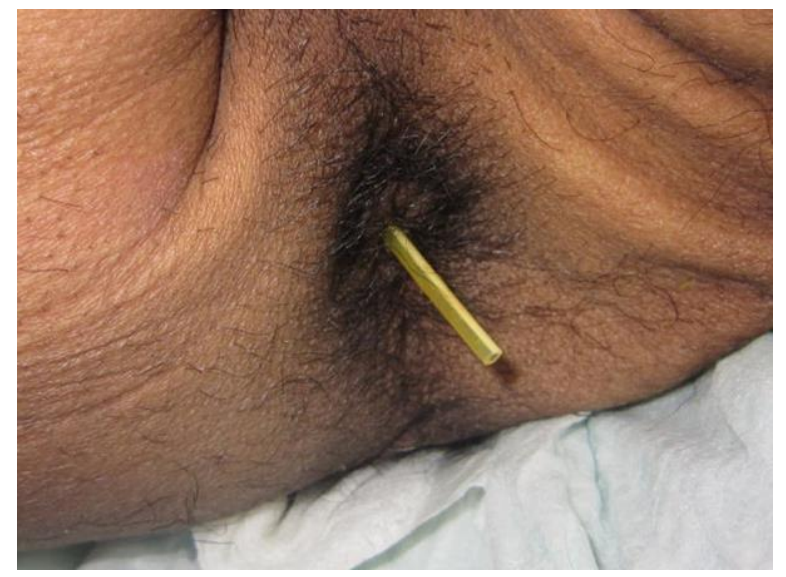

Fig. 2. Peritoneal catheter exiting through the anus.

The exact pathogenesis of shunt-related organ perforation and extrusion through the anus is unclear, and various mechanisms have been suggested, including technical error, foreign body reaction, pressure necrosis and poor general condition with weakening of the intestinal wall and the stiff end off the shunt tube causing perforation (Sathyanarayana et al 2000, Vinchon et al 2006, Glatstein et al 2011, Filho et al 2013). Another mechanism proposed is occult shunt infection and chronic inflammation caused by intraoperative contamination (Vinchon et al 2006). The majority of cases in the literature had a delayed presentation after surgery, which suggests a chronic process rather than a traumatic or technical error. The risk factors for bowel perforation are age, male gender, poor general condition, malnutrition, infection and previous abdominal operation (Griffith \& DeFeo 1987, Agarwal et al 2011, Filho et al 2013, Gupta et al 2014). Among these factors, age is a prominent factor for bowel perforation (Park et al 2000, Odebode 2007, Sinnadurai \& Winder, 2009, Filho et al 2013). Because of weak bowel musculature and stronger peristaltic activity, children are more susceptible to bowel perforation than adult patients (Sathyanarayana et al 2000, Vinchon et al 2006, Glatstein et al 2011, Filho et al 2013). The majority of reports describe more children suffered than adults (Filho et al 2013). Seventy-eight percent of the reported cases occurred in children (Sathyanarayana et al 2000). In the present case, is a rare adult case, different from children, the possible mechanism of bowel perforation could be a persistent vegetative state with chronic immobilization that leads to continuous irritation of a fixed position of shunt tip that continuously erode and then finally perforate the organ. After perforated the bowel, the catheter propelled distally by peristalsis until the tip extruded through an anal orifice.

\section{CONCLUSION}

Bowel perforation and transanal extrusion of VP shunt catheter is a rare but serious problem. In adult shunted patient, one of the risk factors is related to PVS with chronic immobilization, the clinician should be aware of this. We describe the extrusion of a VP shunt catheter through the anus in a 51-year-old persistent vegetative state male patient. Our case emphasizes the possible risk factors to be aware and the importance of early shunt removal to avoid further complications.

\section{REFERENCES}

Agarwal M, Adhana R, Namdev H, Yadav YR, Agrawal $\mathrm{T}$ (2011). Transoral extrusion of the ventriculoperitoneal shunt: A case report and review of literature. Journal of Pediatric Neurosciences 6, 149151. doi: https://dx.doi.org/10.4103/1817-1745.92847

Birbilis T, Zezos P, Liratzopoulos N, Oikonomou A, Karanikas M, Kontogianidis K, Kouklakis G (2009). Spontaneous bowel perforation complicating ventriculoperitoneal shunt: a case report. Cases journal 2, 8251. doi: 10.4076/1757-1626-2-8251

Filho PMM, Agostini DD, Silva RdosS, Junior NDA, Winkelmann L, Zambonin D (2013). Bowel Perforation and extrusion of a ventriculo-peritoneal shunt through the anus. Brazilian Journal of Neurosurgery 24, 69-74

Glatstein M, Constantini S, Scolnik D, Shimoni N, Roth J (2011). Ventriculoperitoneal shunt catheter protrusion through the anus: Case report of an uncommon complication and literature review. Child's Nervous System 27, 2011-2014. doi: 10.1007/s00381012-1701-4

Griffith JA, DeFeo D (1987). Peroral extrusion of a ventriculoperitoneal shunt catheter. Neurosurgery 21, 259-261. Available at: http://www.ncbi.nlm.nih.gov/ pubmed/3309717. Accessed March 21, 2017

Gupta R, Mala TA, Gupta, A Paul, R Malla, S. A. and Gupta, A. K (2014). Transoral migration of peritoneal end of ventriculoperitoneal shunt with perforation of gastro-esophageal junction: A case report of a rare complication. Bangladesh Journal of Medical Science, 13, 492-495. doi: 10.3329/bjms.v13i4.20654

Matsuoka H, Takegami T, Maruyama D (2008). Transanal Prolapse of a Ventriculoperitoneal Shunt Catheter-Case Report. Neurologia medico-. Available at: http://jlc.jst.go.jp/JST.JSTAGE/nmc/48.526?from= Google. Accessed October 24, 2016

Murthy KR, Reddy SJ (2009). Perforation of the distal end of the ventriculoperitoneal shunt into the bladder with calculus formation. Pediatric. Available at: http://www.karger.com/Article/Fulltext/204904.

Accessed: November 22, 2016 
Odebode TO (2007). Jejunal perforation and peroral extrusion of a peritoneal shunt catheter. British Journal of Neurosurgery 21, 235-236. doi: 10.1080/02688690701264346

Park C-K, Wang K-C, Seo J-K, Cho B-K (2000). Transoral protrusion of a peritoneal catheter: a case report and literature review. Child's Nervous System 16, 184-189. doi: 10.1007/s003810050491

Sathyanarayana S, Wylen EL, Baskaya MK, Nanda A (2000). Spontaneous bowel perforation after ventriculoperitoneal shunt surgery: case report and a review of 45 cases. Surgical neurology 54, 388-396

Sinnadurai M, Winder MJ (2009). Silicone spaghetti. Journal of Clinical Neuroscience 16,1348-1350. doi: 10.1016/j.jocn.2008.12.029

Sridhar K, Karmarkar V (2009). Peroral extrusion of ventriculoperitoneal shunt: case report and review of literature. Neurology India 57, 334-6. doi: 10.4103/ 0028-3886.53283

Vinchon M, Baroncini M, Laurent T, Patrick D (2006). Bowel perforation caused by peritoneal shunt catheters: Diagnosis and treatment. Neurosurgery 58, 76-82. doi: 10.1227/01.NEU.0000192683.26584.34

Yazar U, Kanat A, Akca N, Gazioglu G, Arda IS, Kazdal H (2012). Urethral protrusion of the abdominal catheter of ventriculoperitoneal shunt: Case report of extremely rare complication.. Journal of pediatric neurosciences. Wolters Kluwer -- Medknow Publications 7, 111-3. doi: 10.4103/1817-1745.102571

Yilmaz MB, Egemen E, Tonge M, Kaymaz M (2011). Transoral protrusion of a peritoneal catheter due to gastric perforation 10 years after a ventriculoperitoneal shunting - case report and review of the literature. Turkish Neurosurgery 23, 285-8. doi: 10.5137/1019-5149.JTN.4904-11.1 